\title{
PELAKSANAAN PERIZINAN USAHA MIKRO DAN KECIL DI KECAMATAN KUTA SELATAN
}

\author{
Kadek Wifika Novithasari, Fakultas Hukum Universitas Udayana, \\ e-mail: fikanovitasari09@gmail.com \\ I Ketut Westra, Fakultas Hukum Universitas Udayana, \\ e-mail: ketutwestrafh@gmail.com
}

doi: https://doi.org/10.24843/KS.2020.v08.i11.p12

\begin{abstract}
ABSTRAK
Tujuan dari penelitian ini yaitu untuk mengetahui faktor-faktor yang mempengaruhi usaha mikro kecil belum memiliki izin usaha, serta; untuk mengetahui upaya penyelesaian terkait masih banyaknya usaha mikro kecil yang belum memiliki izin usaha. Penelitian dengan menggunakan metode deskriptifkualitatif, dengan memfokuskan pada observasi lapangan dan wawancara beberapa pihak terkait dilakukan untuk mencapai tujuan atau sasaran yang penulis kehendaki. Informan dalam penelitian ini adalah Staff Kontrak Dinas Perizinan Wilayah Kuta Selatan Pusat Pemerintahan Kabupaten Badung; Sub Bagian Pelayanan Umum Kantor Kecamatan Kuta Selatan; Customer Service Bank BRI Desa Ungasan; Para pelaku usaha Mikro dan Kecil di Kecamatan Kuta Selatan. Hasil penelitian menunjukkan bahwa penerapan legalitas bentuk usaha mikro dan kecil di Kecamatan Kuta Selatan faktanya masih terdapat beberapa kendala atau faktor-faktor yang mempengaruhi usaha mikro kecil belum mengurus izin usahanya, seperti; SOP yang harus dipenuhi, keterlibatan oknum dalam pengurusan izin secara manual, dan kurangnya sosialisasi serta kesadaran masyarakat. Upaya penyelesaiannya bagi pelaku usaha yang enggan mengurus izinnya secara manual, Pemerintah telah membuatkan program OSS (Online System Submission) sehingga akan lebih mempermudah Pelaku Usaha Mikro Kecil (PUMK) mengurus izin usahanya.
\end{abstract}

Kata kunci: Penerapan, Legalitas, Kendala, Mikro, Kecil.

\begin{abstract}
The purpose of this study is to determine the factors that affect micro and small businesses that do not have a business license, and; This is to determine the resolution efforts related to the large number of micro and small businesses that do not have business licenses. Research using descriptive-qualitative methods, focusing on field observations and interviews of several related parties were carried out to achieve the goals or objectives that the writer wanted. The informants in this study were the Contract Staff of the South Kuta Regional Licensing Service, Central Government of Badung Regency; Sub Division of Public Services Office of South Kuta District; Bank BRI Customer Service in Ungasan Village; Micro and Small entrepreneurs in South Kuta District. The results showed that the application of the legality of micro and small business forms in South Kuta District, in fact, there are still several obstacles or factors that affect micro and small businesses that have not processed their business licenses, such as; SOPs that must be met, involvement of individuals in manual permit processing, and lack of socialization and public awareness. Efforts to solve it for business actors who are reluctant to take care of their permits manually, the Government has created an OSS (Online System Submission) program so that it will make it easier for micro and small entrepreneurs (PUMK) to process their business permits.
\end{abstract}

Keywords: Application, Legality, Constraints, Micro, Small. 


\section{Pendahuluan}

\subsection{Latar Belakang Masalah}

Usaha mikro dan kecil memiliki peran yang teramat penting dalam laju pertumbuhan ekonomi yang kian melemah. ${ }^{1}$ Eksistensi usaha mikro dan kecil tidak akan dapat berkembang tanpa ditunjang oleh suatu legalitas atau kepastian hukum yang dapat menjamin keberadaan bentuk usaha tersebut. Salah satu hal yang dapat menjamin kepastian hukum dalam mendirikan bentuk usaha mikro dan kecil yaitu, adanya izin. ${ }^{2}$ Terkait dengan pentingnya perlindungan suatu bentuk usaha, Pemerintah telah mengatur eksistensi UMKM di Indonesia yaitu melalui UndangUndang Nomor 20 Tahun 2008 tentang Usaha Mikro, Kecil dan Menengah. ${ }^{3}$ Materi muatan dalam Undang-Undang tersebut pada hakekatnya sudah cukup jelas, lengkap dan dapat diterapkan, seperti misalnya yang akan dibahas selanjutnya dalam tulisan ini mengenai "Perizinan"nya yang telah tersurat secara lengkap dalam Pasal 12 Undang-Undang UMKM terkait dengan aspek perizinannya, serta tata cara pelaksanaanya lebih lengkap dapat dilihat dalam Bab IV pada Peraturan Pemerintah Nomor 17 tahun 2013 tentang Pelaksanaan Undang-Undang UMKM tersebut, mulai dari Bentuk Perizinan; Penyederhanaan Tata Cara Perizinan; Tata Cara Permohonan Izin Usaha; Biaya Perizinan; Informasi Izin Usaha hingga Pembinaan dan Pengawasan.

Semua hal tersebut yang pada akhirnya perlu diperhatikan oleh para dan atau calon pelaku usaha yang hendak mengurus izin usahanya. Kepemilikan izin usaha menjadi hal yang paling utama untuk dipertimbangkan oleh pelaku usaha untuk menjamin perlindungan dan kepastian usaha yang hendak dikembangkannya. Secara khusus, lingkup tulisan ini hanya akan membahas mengenai perizinan usaha mikro dan kecil di Kecamatan Kuta Selatan, sehingga penting untuk diketahui pengetahuan dasar terkait perbedaan antara usaha mikro dan kecil. Berdasarkan Undang-Undang UMKM, berikut adalah perbedaannya: Usaha Mikro biasanya berbentuk badan usaha perorangan dengan paling banyak kekayaan bersih Rp 50.000.000,- (lima puluh juta rupiah) dan omzet per tahun maksimal Rp 300.000.000,- (tiga ratus juta rupiah). Sedangkan, Usaha Kecil adalah milik orang perorangan yang tidak bergantung pada suatu perusahaan atau terikat sebagai cabang perusahaan, sehingga dimiliki dan dikelola oleh pemilik itu sendiri. Kekayaan bersihnya berkisar antara Rp 50.000.000,(lima puluh juta rupiah) hingga maksimal Rp 500.000.000,- (lima ratus juta rupiah) serta omzet per tahun Rp 300.000.000,- (tiga ratus juta rupia) hingga Rp 2.500.000.000,(dua milyar lima ratus juta rupiah). Perbedaan tersebut yang nantinya akan membantu Penulis dan juga para pembaca untuk membedakan antara usaha mikro dan kecil.

Dalam faktanya, masih ada usaha mikro kecil yang belum memiliki izin usaha. Padahal dewasa ini, legalitas izin bentuk usaha mikro dan kecil sangatlah penting, mengingat banyaknya masyarakat yang kesulitan mengembangkan usahanya serta para usahawan yang sulit mendapatkan kontribusi modal/dana untuk pengembangan usahanya karena belum terdaftar atau mendapat izin dari pemerintah. ${ }^{4}$ Salah satu faktor yang kerap digandrungi sebagai penyebab para pelaku usaha enggan untuk

\footnotetext{
${ }^{1}$ Sumawinata, Sarbini. Politik Ekonomi Kerakyatan (Jakarta: Gramedia Pustaka Utama, 2004), h. 161.

${ }^{2}$ Dewi, Gusti Ayu Krisna, Putu Nomy Yasintha dan Putu Eka Purnamaningsih. "Implementasi Kebijakan Izin Usaha Mikro dan Kecil (IUMK) di Kecamatan Denpasar Barat". Jurnal Ilmu Sosial dan Ilmu Politik Universitas Udayana.

${ }^{3}$ Undang-Undang Republik Indoensia Nomor 20 tahun 2008 tentang UMKM.

${ }^{4}$ International Labour Organization. 2014. "Policies for The Formalization of Micro and Small Enterprises". Latin America And the Caribbean: Author.
} 
mengurus izin usahanya yaitu dikarenakan proses pembuatan izin usaha memakan waktu yang terbilang cukup panjang.

Pemerintah kembali menetapkan suatu Peraturan Presiden yang secara tidak langsung mewajibkan masyarakat terkhusus para pelaku usaha untuk tidak mengabaikan suatu izin/legalitas dalam menjalankan kegiatan usaha, walau kecil sekalipun (Peraturan Presiden Nomor 98 Tahun 2014 Tentang Perizinan Untuk Usaha Mikro dan Kecil) ${ }^{5}$, yaitu tersirat dalam Pasal 4 ayat (4) bahwa dilakukan pendataan terhadap pelaku usaha mikro dan kecil oleh Lurah/Kepala Desa di wilayah kerjanya. Selain itu, disebutkan juga dalam Pasal 2 Peraturan Presiden tersebut bahwa maksud digencarkannya izin usaha ini dilakukan dengan beberapa maksud dan tujuan, salah satunya yaitu untuk menjamin kepastian dan perlindungan hukum bagi para pelaku usaha. Terlebih lagi, Pengurusan IUMK (Izin Usaha Mikro Kecil) kini diprogramkan lebih efektif dan efisien, yaitu dengan sistem online OSS (Online Single Submission), sehingga semakin mempermudah para pelaku usaha mengurus izin usahanya, terutama yang berada di Kecamatan Kuta Selatan hingga tidak perlu lagi mengurusnya secara manual ke Pusat Pemerintahan Kabupaten Badung.

Kecamatan Kuta Selatan adalah sebuah kecamatan di Kabupaten Badung yang belakangan ini menjadi sorotan para wisatawan untuk dikunjungi. Karenanya, pertumbuhan penduduk dan perkembangan usaha di kecamatan ini pun makin berkembang pesat, mulai dari usaha mikro kecil hingga usaha besar sekalipun. Penulis menggunakan wilayah Kuta Selatan sebagai objek teliti dikarenakan selain wilayahnya yang baru beberapa tahun mengalami perkembangan, wilayah ini juga merupakan tempat tinggal Penulis, sehingga memudahkan Penulis untuk terjun ke lapangan mencari data yang dibutuhkan. Berangkat dari Analisa Penulis melihat lingkungannya yang mengalami perkembangan pesat hingga di sepanjang jalan telah dipenuhi dengan deretan kios-kios dagang, mulai dari yang usaha mikro (seperti, pedagang kaki lima, pedagang-pedagang di pasar, bengkel, salon kecantikan, penjahit, dan sebagainya), usaha kecil (seperti, pedagang grosir (agen), koperasi berskala kecil, pemilik tanah perorangan yang memiliki tenaga kerja, dan lain sebagainya), hingga usaha besar. Melihat perkembangan tersebut, Penulis yakin bahwa usaha-usaha mikro dan kecil yang berderet di sepanjang jalan tersebut belum semua memiliki izin usaha, dan hal tersebut yang menarik perhatian Penulis untuk meneliti lebih lanjut terkait tentang seberapa pentingnya izin usaha dalam kacamata para pelaku usaha tersebut, utamanya usaha mikro dan kecil.

Terkait dengan Orisinalitas Penelitian atau keaslian suatu karya penelitian, Penulis yakin bahwa karya tulisan ini belum ada yang meneliti, terkhusus di wilayah Kuta Selatan. Namun, Penulis akan mencantumkan beberapa karya penelitian yang serupa tetapi tetap memilik suatu perbedaan yang signifikan. Penelitian yang pertama pernah dilakukan oleh Ayu Lestari Nadela, yang melakukan Penelitian tentang "Penerapan Izin Usaha Mikro dan Kecil di Kecamatan Tampan Pekanbaru". 6 Dalam penelitian tersebut memang ada kesamaan dengan penelitian Penulis yaitu tentang metode penelitian yang digunakan, namun metode penelitian yang digunakan Ayu Lestari Nadela untuk menyusun tulisannya lebih menekankan pada teori Syafiie yang terdiri dari tahap perencanaan hingga tujuan sasaran. Perbedaannya dengan penelitian

\footnotetext{
${ }^{5}$ Peraturan Presiden Nomor 98 Tahun 2014 Tentang Perizinan Untuk Usaha Mikro dan ecil,
}

Pasal 2.

${ }^{6}$ Lestari N., Ayu. "Penerapan Izin Usaha Mikro dan Kecil di Kecamatan Tampan Pekanbaru”. Jurnal Administrasi Negara FISIP Universitas Riau, 4 (2017), 1-15. 
yang dilakukan oleh Penulis adalah, Penulis lebih menekankan pada penyusunan dengan teknik sistematis dan teratur sesuai narasumber dan informan yang dikunjungi, sehingga tulisan ini akan lebih tampak real dengan tulisan terdahulu.

Selanjutnya jika dibandingkan dengan Penelitian yang dilakukan oleh Heri Kusmanto dan Warjio tentang "Pentingnya Legalitas Usaha bagi Usaha Mikro Kecil dan Menengah". ${ }^{7}$ Dalam penelitian tersebut memiliki isi yang tidak jauh berbeda dengan penelitian Penulis yaitu tentang pentingnya izin suatu Usaha. Namun yang menjadi pembeda disini ialah Penulis menyajikan tulisan ini dengan tujuan menyasar Usaha Mikro Kecil saja dan memiliki studi kasus yang mengkhusus yaitu di Kecamatan Kuta Selatan, sedangkan yang diteliti oleh Heri Kusmanto dan Warjio lebih kepada sisi norma yang menargetkan seluruh pelaku UMKM.

Penelitian selanjutnya yang Penulis bandingkan adalah Penelitian oleh Gusti Ayu Krisna Dewi, dkk., yang meneliti tentang "Implementasi Kebijakan izin Usaha Mikro dan Kecil (IUMK) di Kecamatan Denpasar Barat". Dalam penelitiannya tersebut Gusti Ayu Krisna Dewi, dkk., hanya mengambil satu permasalahan yang lebih fokus dan mengkrucut yaitu mengenai penerapan IUMK di Denpasar Barat. Sedangkan Penulis meneliti di Kecamatan Kuta Selatan yang pasti akan memiliki hasil data implementasi yang berbeda dengan rumusan masalah yang berbeda pula dengan penelitian terdahulu tersebut.

Setelah mengkaji ketiga hasil penelitian diatas, Penulis simpulkan bahwa tulisan yang diteliti oleh Penulis berbeda dengan penelitian-penelitian terdahulu dan telah mengandung unsur kebaruan dan orisinil, sehingga hasil dari penelitian Penulis ini akan dapat digunakan sebagai tambahan wawasan bagi kita semua.

Sehingga dengan demikian, sangat menarik untuk diteliti mengenai "Pelaksanaan Perizinan Usaha Mikro dan Kecil di Kecamatan Kuta Selatan".

\subsection{Rumusan Masalah}

1. Apakah faktor-faktor yang mempengaruhi usaha mikro kecil belum memiliki izin usaha?

2. Bagaimanakah upaya penyelesaian terkait masih banyaknya usaha mikro kecil yang belum memiliki izin usaha?

\subsection{Tujuan Penulisan}

1. Untuk mengetahui dan menganalisis tentang faktor-faktor yang mempengaruhi usaha mikro kecil belum memiliki izin usaha, serta;

2. Untuk mengetahui dan menganalisis tentang upaya penyelesaian terkait masih banyaknya usaha mikro kecil yang belum memiliki izin usaha.

\section{Metode Penelitian}

\subsection{Jenis Penelitian}

Dari penggambaran judul, penelitian ini dapat diketahui secara langsung menggunakan metode penelitian Empiris, dikarenakan dilakukan dengan meneliti langsung pelaksanaannya di lapangan, yaitu di wilayah Kuta Selatan dengan tetap memperhatikan regulasi terkait. Digunakannya metode penelitian ini dimaksudkan untuk melihat apakah pada praktiknya telah cocok antara regulasi dengan penerapan

${ }^{7}$ Kusmanto, Heri dan Warjito. "Pentingnya Legalitas Usaha Bagi Usaha Mikro Kecil dan Menengah". JUPIIS: Jurnal Pendidikan Ilmu-IImu Sosial, 11 (2) (2019): 320-327. 
normanya di lapangan serta apakah regulasi yang diterapkan tersebut menimbulkan kesenjangan dalam pengimplementasiannya atau tidak.

\subsection{Lokasi Penelitian}

Perihal lokasi juga telah tersurat dari judul tulisan ini, yaitu dilakukan di Kecamatan Kuta Selatan. Beberapa tempat yang dituju penulis untuk memperoleh keakuratan dan kesinkronan data, yakni; Pusat Pemerintahan Kabupaten Badung bagian Perizinan wilayah Kuta Selatan; Kantor Camat Kuta Selatan; Bank BRI Ungasan-Kuta Selatan; Para Pelaku Usaha Mikro, Kecil.

\subsection{Informan Penelitian}

Penulis mendatangi beberapa informan yang dianggapnya mengetahui secara pasti serta dapat memberikan informasi secara pasti terkait penelitian ini, diantaranya; Staff Kontrak Dinas Perizinan Wilayah Kuta Selatan Pusat Pemerintahan Kabupaten Badung; Sub Bagian Pelayanan Umum Kantor Kecamatan Kuta Selatan; Customer Service Bank BRI Desa Ungasan; Para pelaku usaha Mikro dan Kecil di Kecamatan Kuta Selatan.

\subsection{Jenis Pendekatan}

Pendekatannya menitikberatkan pada hasil fakta di lapangan yang kemudian dipacu dengan knowledge yang ada, sehingga dapat menghasilkan untaian kalimat deskriptif dari hasil analisa pemecahan masalahnya. Pendekatan ini lazim disebut pendekatan kualitatif.

\subsection{Sumber Data}

Data primer dan data sekunder adalah dua sumber data yang penulis terapkan dalam penelitian ini. ${ }^{8}$ Data primer dapat diperoleh dari berkenalan langsung dengan lingkungan tempat penelitian, seperti dengan wawancara, kuisioner, atau pengamatan, yang artinya sumber data ada langsung pada wilayahnya, yaitu dalam hal ini adalah Kuta Selatan. Data sekunder adalah kata lain dari teori atau knowledge yang digunakan untuk menunjang bukti-bukti yang diperoleh dari data utama/data primer, seperti bahan kepustakaan yang bersifat teoritis.

\subsection{Teknik Pengumpulan Data ${ }^{9}$}

\subsubsection{Observasi}

Disesuaikan dengan kebutuhan penulis akan bukti konkret terkait objek penelitian, adanya observasi disini merupakan suatu langkah pasti untuk menemukan gambaran nyata di kawasan Kuta Selatan sendiri, karena observasi ini dapat dikatakan sebagai roh daripada penelitian empiris.

\subsubsection{Wawancara}

Teknik yang lazim digunakan untuk menjangkau informasi lebih banyak lagi adalah wawancara. Melalui teknik wawancara, informasi terkait Pelaksanaan Perizinan Usaha Mikro dan Kecil di Kecamatan Kuta Selatan dapat memperoleh

${ }^{8}$ Putra, Gede Surya Prtama dan Mustika, Made Dwi Setyadhi. "Efektivitas Program Jamkrida Dan Dampak Terhadap Pendapatan Dan Penyerapan Tenaga Kerja UMKM." E-Jurnal Ekonomi Pembangunan Universitas Udayana 3, No. 12 (2014).

${ }^{9}$ Tampan, Abner., Rumapea, Patar \& Pombengi, Jericho. "Implementasi Kebijakan Pemberian Izin USAha Mikro dan Kecil di Kantor Kecamatan Malalayang Kota Manado". Jurnal Universitas Sam Ratulangi. 2016. 
banyak sudut pandang dari narasumber dan informan, sehingga data-data tersebut dapat dikumpulkan, dipilah atau disatukan menjadi kesatuan data yang akurat.

\subsection{Teknik Analisis}

Tahap analisis ini dilakukan dengan menggabungkan, membandingkan ataupun memperjelas hasil analisis dengan penambahan teori-teori yang ada, sehingga terbentuk kesinkronan antara hasil dengan permasalahan yang hendak dipecahkan dalam penelitian ini. Metode ini kerap kali disebut metode deskriptif kualitatif. ${ }^{10}$

\section{Hasil dan Pembahasan}

\subsection{Faktor-Faktor Yang Mempengaruhi Usaha Mikro Kecil Belum Memiliki Izin Usaha}

Legalitas formal suatu badan usaha merupakan suatu keharusan yang dimiliki oleh tiap-tiap pemilik usaha. Legalitas tersebut menandakan suatu badan usaha telah mendapat pengakuan yang sah secara hukum dan resmi untuk dioperasikan. Adanya pengakuan yang sah terhadap suatu bentuk usaha dapat mempermudah dalam mengakses permodalan; serta Kemudahan menjalin kerjasama dengan pihak lain juga dapat dirasakan ketika suatu bentuk usaha telah memiliki izin usaha resmi secara hukum.11 Selain itu, setiap warga negara memiliki kewajiban untuk membayar pajak, terlebih lagi bagi pelaku usaha yang akan dikenakan pajak sesuai dengan bentuk dari legalitas usaha yang dimilikinya. Adaya izin usaha tersebut juga membantu perolehan devisa negara melalui kontribusi yang diberikan oleh setiap pelaku usaha dalam membayar pajak untuk kepentingan badan usahanya. ${ }^{12}$

Tujuan diberlakukannya kebijakan mengenai penerapan legalitas bentuk usaha mikro dan kecil adalah dengan maksud memberikan pemecahan atas masalah yang dihadapi masyarakat dalam ruang lingkup menjalankan suatu usaha. Hal tersebut sesuai dengan Peraturan Presiden Nomor 98 Tahun 2014 Tentang Perizinan untuk Usaha Mikro dan Kecil, serta peraturan Menteri Dalam Negeri Nomor 83 Tahun 2014 Tentang Pedoman Pemberian Izin Usaha Mikro dan Kecil. Namun, tidak dapat dipungkiri dalam penerapan legalitas usaha ini masih ada usaha mikro kecil yang belum memiliki izin usaha. Adapun beberapa faktor yang mempengaruhi usaha mikro kecil di Kecamatan Kuta Selatan ini masih belum memiliki izin usaha, diantaranya:

a) SOP yang harus dipenuhi

Seringkali PUMK saat mengurus izin usahanya secara manual tidak memenuhi persyaratan (SOP) secara lengkap, sehingga mengharuskan mereka untuk kembali dan melengkapi SOP tersebut. Hal itu juga yang akan menghambat penyelesaiaan izin tersebut. ${ }^{13}$

b) Keterlibatan Oknum dalam Pengurusan Izin Secara Manual

Penerbitan izin yang sudah lengkap biasanya paling lambat diselesaikan dalam waktu satu hari sesuai dengan Peraturan Menteri Dalam Negeri Nomor 83

\footnotetext{
${ }^{10}$ Nazir, Mohammad. Metode Penelitian (Jakarta: Penerbit Ghalia Indonesia, 2015) h.25.

${ }^{11}$ Julita, Ami. "Pelaksanaan Izin Usaha Mikro dan Kecil (IUMK) Gratis di Kecamatan Sukajadi Kota Pekanbaru." Jurnal JOM FISIP 4, No. 1 (2017).

${ }^{12}$ Tambunan, Tulus T.H. UMKM di Indonesia (Jakarta: Ghalia Indonesia, 2010), h. 45.

${ }^{13}$ Suwandi. "Perizinan Usaha UMKM, Buletin Peraturan di Bidang Koperasi dan UMKM, Kementerian Koperasi dan UKM". Volume 3 Juni 2012, Halaman 1-6.
} 
Tahun 2014 Tentang Pedoman Pemberian Izin Usaha Mikro dan Kecil Pasal 9 ayat 5.14 Namun pada kenyataannya tidak dilaksanakan sesuai pedoman yang ada, dari yang seharusnya dalam pengurusan izin tidak dikenai biaya sepeser pun, jadi harus menanggung biaya, belum lagi diulurnya waktu pengeluaran izin tersebut. Hal-hal seperti itu yang harus segera ditindaklanjuti agar masyarakat tidak enggan lagi dalam mengurus izin.

c) Kurangnya Sosialisasi dan Kesadaran Masyarakat ${ }^{15}$

Sosialisasi sangat penting adanya untuk menunjang seluruh masyarakat mengetahui informasi yang diperlukan, terkhusus dalam hal ini mengenai pentingnya legalitas suatu bentuk usaha, dari usaha yang besar hingga kecil sekalipun. Namun, sosialisasi saja tidak akan efektif apabila masyarakat atau PUMK itu sendiri tidak memiliki kesadaran untuk mengurus izin usahanya.

Dari hasil wawancara yang Penulis lakukan di Kantor Camat dengan Narasumber Ibu Margi, Bagian Pelayanan Umum, Bidang Perijinan Kantor Camat Kuta Selatan ${ }^{16}$, Penulis mendapatkan informasi bahwa masih banyaknya pelaku usaha mikro dan kecil di Kecamatan Kuta Selatan yang belum bahkan tidak tahu sama sekali mengenai perizinan tersebut, padahal pentingnya suatu legalitas/izin dalam mendirikan dan menjalankan suatu usaha sudah mulai diperkenalkan sejak tahun 2016 lalu melalui sosialisasi. Saat itu pengurusan izin masih menggunakan cara manual dengan dicatatkan di kecamatan dan surat izinnya langsung dicetakkan. Cara manual tersebut membuat surat izin usaha memiliki batasan waktu untuk masa berlakunya, yaitu lima tahun untuk usaha tetap. Tetapi jika dalam keadaan kontrak atau milik sendiri dengan usaha sementara harus minimal satu tahun usaha tersebut berjalan, kurang dari itu, misalnya 6 bulan, maka tidak bisa diberikan izin usaha.

Di Kecamatan Kuta Selatan sendiri terdapat pembagian tugas yang dibagi menjadi enam seksi, yaitu: Seksi Pelayanan; Seksi Terantib; Seksi Umum; Seksi Keuangan; Seksi Pemerintahan; dan Seksi Pembangunan. Dari keenam seksi atau pembagian tugas tersebut, Seksi Terantib yang paling berperan dalam hal pengawasan di Lapanan. Dengan adanya pengawasan di lapangan dan kunjungan terhadap para pelaku usaha, secara tidak langsung telah dilakukannya sosialisasi dan hal tersebut akan sangat membantu para pelaku usaha mikro maupun kecil yang baru mendirikan usaha dan tidak tahu mengenai perizinan tersebut. Meskipun masih banyak yang mengabaikan pengurusan izin usaha tersebut, namun narasumber mengatakan saat ini perkembangannya lumayan membaik dan menunjukkan adanya partisipasi masyarakat terhadap program atau aturan yang telah ditetapkan oleh Pemerintah.

Salah satu faktor pemicu enggannya para pelaku usaha, utamanya usaha mikro dan kecil untuk mengurus izin usahanya yaitu karena mereka menganggap bahwa usaha dengan kapasitas kecil tidak memerlukan sebuah izin. Padahal pengurusan izin usaha terutama untuk usaha dengan kapasitas kecil akan memberikan banyak manfaat terhadap pelaku usaha itu sendiri. Selain untuk mendapatkan perlindungan

\footnotetext{
${ }^{14}$ Pasal 9 ayat 5, Peraturan Menteri Dalam Negeri Nomor 83 Tahun 2014 Tentang Pedoman Pemberian Izin Usaha Mikro dan Kecil.

${ }^{15}$ Adawiyah, Wiwiek Rabiatul. "Faktor Penghambat Pertumbuhan Usaha Mikro Kecil Menengah (UMKM): Studi di Kabupaten Banyumas". Jurnal Ekonomi Universitas Jenderal Soedirman. 2013. Selatan.

16Wawancara pada Rabu, 30 Oktober 2019, Pukul 15.00 wita di Kantor Kecamatan Kuta
} 
dan kepastian hukum, izin usaha juga dapat menghantarkan para pelaku usaha untuk melebarkan sayap untuk usaha mereka yaitu dengan mendapatkan pinjaman modal dari bank untuk mengembangkan usaha yang dimilikinya.

Standar pengawasan dari pelaksanaan perizinan usaha mikro dan kecil ini lebih ditekankan pada; apakah pelaksanaan perizinan di Kecamatan Kuta Selatan telah berjalan sebagaimana mestinya sesuai dengan peraturan perundang-undangan, apakah muncul kendala dalam pelaksanaannya dan apakah masih banyak pelaku usaha yang membangkang dengan kebijakan ini. Disinilah peran camat dan para pendamping yang langsung terjun ke lapangan untuk mengawasi sekaligus menindaklanjuti hal tersebut apabila pelaksanaan perizinan usaha mikro dan kecil ini tidak sesuai dan menyimpang dari kebijakan atau pedoman mengenai pemberian izin usaha mikro dan kecil yang telah tercantum dalam PERMENDAGRI (Peraturan Menteri Dalam Negeri Nomor 83 Tahun 2014 tentang Pedoman Pemberian Izin Usaha Mikro dan Kecil).

Selain itu, kendala atau faktor yang mempengaruhi pelaku usaha enggan untuk mengurus izinnya, yaitu terkait dengan standar operasional prosedur (SOP) yang belum lengkap atau tidak dipenuhi saat melakukan kepengurusan secara manual. Hal tersebut tentu menguji kesabaran para pelaku usaha dengan harus bolak-balik melengkapi prosedur yang telah ditetapkan. Tak hanya itu, kesadaran masyarakat akan pentingnya izin usaha tersebut dan pola pikir yang menganggap bahwa usaha dengan kapasitas kecil tidak memerlukan suatu izin usaha yang masih sangat perlu diubah dalam masyarakat kita.

Kini, masyarakat sangat dipermudah dengan adanya kecanggihan teknologi, sehingga kepengurusan izin usaha telah dapat diakses secara online. Namun, bukan berarti cara manual tidak lagi digunakan. Cara manual tetap dapat digunakan terkhusus masyarakat yang hendak mengurus izin namun terkendala 'gaptek' atau tidak mampu memfungsikan teknologi dengan baik, cara manual tetap dapat dilakukan dengan datang langsung ke Kantor Kecamatan atau ke Pusat Pemerintahan Kabupaten Badung sehingga surat izin usaha dapat langsung dicetakkan. Pengurusan izin usaha tersebut pun tidak memungut biaya, oleh karena itu, baik manual ataupun online akan sangat friendly di masyarakat.

Selain melakukan wawancara di Kantor Camat, Penulis juga mendatangi Bank BRI Cabang Ungasan untuk mengetahui lebih jelas keterkaitan antara izin usaha dan kredit di bank. Penulis mewawancarai Narasumber dengan nama Bapak Aditya, selaku Customer Service di Bank BRI Cabang Ungasan, Kuta Selatan ${ }^{17}$. Sebagai sebuah bank, fungsi utamanya tidak lain dan tidak bukan adalah untuk menyerap dana dari masyarakat dan menyalurkanya kembali ke masyarakat dalam bentuk kredit. Tentu bank juga familiar dengan kata mengakses modal. Era globalisasi telah membuat seluruh aspek mengalami perkembangan yang begitu pesat, tanpa terkecuali sebuah usaha. Masyarakat berbondong-bondong ingin mengembangkan usaha-usaha yang dimilikinya, karena itu merupakan sebuah asset investasi untuk masa depan para pebisnis tersebut. Akan tetapi, tak jarang para pelaku usaha mengabaikan pentingnya suatu izin usaha diawal pendirian usaha mereka, sehingga ketika hendak mengakses modal dan tidak mengetahui standar operasional prosedur sebuah bank dalam meminjamkan uang kepada nasabahnya, para pelaku usaha ini pun akan berakhir 'kelabakan', disatu sisi harus segera mengurus izin usaha yang

17Wawancara pada Rabu, 30 Oktober 2019, Pukul 16.00 wita di Bank BRI Cabang Ungasan, Kuta Selatan. 
dimilikinya dan di sisi lain juga harus menyiapkan syarat-syarat lainnya yang diperlukan untuk mengakses modal tersebut di bank.

Seperti yang telah Penulis wawancarai, Narasumber di Bank BRI cabang Ungasan tersebut menyatakan masih ada saja pelaku usaha yang tidak memiliki izin usaha tetapi tetap memaksakan untuk meminjam uang di bank tersebut. Alhasil, demi keamanan dan kenyamanan bersama, pihak bank menyarankan agar segala sesuatu sebaiknya selaras dengan prosedur atau SOP yang tersedia, terlebih lagi persoalan mengakses modal di bank, memang terdapat syarat-syarat yang harus dipenuhi, jika syarat tak dipenuhi maka pelaku usaha ini tidak bisa mengajukan pinjaman. Mengenai syarat-syarat sebenarnya cukup simpel, yaitu yang pertama bahwa pelaku usaha yang hendak melakukan pinjaman guna mengakses modal harus benar-benar memiliki sebuah usaha yang real, karena bagaimana hendak mengajukan alasan terkait permodalan jika usaha yang hendak dimodalkan tidak ada alias fiktif? Oleh sebab itu, kepemilikan surat izin usaha, meski usaha dengan kapasitas kecil sekalipun menjadi sangat penting dan dapat dijadikan bukti konkret atas kepemilikan suatu usaha yang sah. Meskipun dalam hal ini surat izin usaha dapat dikatakan menjadi syarat mutlak untuk memperoleh pinjaman modal, tetapi syarat-syarat lainnya tidak kalah pentingnya, seperti KTP (kartu tanda penduduk), KK (kartu keluarga), jaminan/agunan, dan lain-lain, karena satu syarat saja tidak dipenuhi maka pelaku usaha yang ingin mengakses modal harus melengkapinya terlebih dahulu.

Selain narasumber, Penulis juga mewawancarai beberapa pelaku usaha mikro kecil sebagai informan, yaitu diantaranya beberapa warung kecil, grosir, bengkel, dan laundry ${ }^{18}$. Dari keseluruhan informan yang telah diwawancarai Penulis, beberapa diantaranya belum memiliki izin usaha dengan alasan masih tergolong warung kecilkecilan sehingga menurut mereka izin usaha belum terlalu penting adanya. Ini merupakan salah satu faktor yang mempengaruhi tidak terlaksananya program dan aturan pemerintah dengan baik, yaitu kurangnya kesadaran masyarakat akan pentingnya mengurus legalitas atau izin usaha yang mereka dirikan. Namun, dibalik itu semua, Penulis juga mendapati beberapa usaha mikro kecil lainnya yang telah memiliki izin usaha. Secara keseluruhan pelaku usaha mikro kecil telah mengetahui pentingnya izin usaha tersebut, namun beberapa dari mereka memang enggan untuk mengurusnya dan berpikir bahwa usaha mereka hanyalah usaha kecil-kecilan sehingga dirasa tidak perlu mengurus izin usaha. Beberapa dari mereka juga berpikir bahwa mengurus izin akan memakan biaya, meskipun dikatakan gratis, mereka tetap menganggap akan ada saja oknum yang meminta imbalan atas kepengurusan tersebut.

Dari beberapa narasumber yang Penulis datangi, sebagaian besar mengaku bahwa tidak pernah diadakan sosialisasi terkait hal tersebut, tetapi ada satu pelaku usaha yaitu Bapak Suparman (pemilik bengkel) mengaku pernah dilakukan sosialisasi di lingkungannya dan juga pernah didatangi oleh petugas, namun petugas hanya datang untuk menanyakan dan tidak mengenakan denda jika tidak membuat atau mengurus izin usaha. Pada hakekatnya, bukan persoalan diterapkan atau tidaknya sanksi dalam hal ini, tetapi pentingya kesadaran masyarakat terhadap kebijakan-kebijakan yang telah diprogramkan oleh Pemerintah, sehingga tercipta

18Wawancara para pelaku usaha mikro dan kecil pada Rabu, 30 Oktober 2019, Pukul 16.30 wita di wilayah Kecamatan Kuta Selatan. 
kesejahteraan bersama. Izin usaha mikro kecil ini dicanangkan oleh pemerintah bukan serta merta untuk membantu pemasukan devisa negara, tetapi juga memiliki maksud dan tujuan yang sama-sama menyejahterakan masyarakatnya, terutama bagi para pelaku usaha itu sendiri, karena pada akhirnya izin usaha tersebut akan sangat diperlukan oleh para pelaku usaha untuk mengembangkan usaha mereka melalui akses permodalan di bank, serta pentingnya perlindungan dan kepastian hukum di negara ini juga semestinya menjadi pertimbangan para pelaku usaha di tanah air untuk memperoleh label legal/sah nya usaha yang mereka miliki. Sudah seharusnya masyarakat terkhusus para pelaku usaha mempertimbangkan alasan terkait kendala atau faktor-faktor yang dianggap menghambat tadi dan merubah pola pikir menjadi untuk apa sebenarnya kita diharuskan dalam mengurus izin usaha kita? Bukan perkara menghitung keuntungan yang kita peroleh, tetapi persoalan kesejahteraan bersama yang akan kita dapatkan. Ketika pemerintah membuat suatu kebijakan, peran serta masyarakatnya juga sangat dibutuhkan. Tanpa adanya partisipasi masyarakatnya, suatu kebijakan hanya akan menjadi sia-sia.

\subsection{Upaya Penyelesaian Terkait Masih Banyaknya Usaha Mikro Kecil Yang Belum Memiliki Izin Usaha}

Di era globalisasi seperti ini, teknologi semakin berkembang dan proses pengurusan izin pun semakin berkembang, termasuk dalam hal pengurusan IUMK. Kini Pemerintah dituntut untuk mengerti kebutuhan masyarakat dan mengkolaborasikannya dengan perkembangan teknologi yang ada, sehingga segala sesuatunya dapat berjalan dengan lebih efektif. Untuk mengatasi persoalan terakit masih banyaknya usaha mikro kecil yang belum memiliki izin usaha, Pemerintah telah menerbitkan program pengurusan izin berbasis digital, yaitu dengan sistem OSS (Online System Submission). Dengan diterbitkannya program ini diharapkan akan dapat mempermudah masyarakat dalam proses pengurusan izinnya, dikarenakan hal ini dapat dilakukan di rumah masing-masing dengan login sistem terkait, sehingga pengurusan izin dapat otomatis terdaftar, aman, cepat dan realtime. Sehingga tidak ada lagi alasan untuk para pelaku usaha enggan untuk mengurus izin usaha mereka. Meskipun telah diberlakukannya sistem online seperti tersebut diatas, akan tetapi di masing-masing kecamatan terkhusus di Kecamatan Kuta Selatan tetap menerima pengurusan izin secara manual, untuk melayani masyarakat yang kurang mengerti teknologi dalam pengurusan izinnya.

Penulis telah mendatangi Pusat Pemerintahan Kabupaten Badung untuk melakukan wawancara terkait dengan upaya penyelesaian yang tersedia untuk mengatasi rumusan masalah pertama, dengan Narasumber bernama I Putu Wahyu Sedana Yoga (Staff Kontrak Dinas Perijinan) ${ }^{19}$. Dengan adanya kendala atau beberapa faktor yang telah dijelaskan dalam penjelasan rumusan masalah pertama, upaya penyelesaian adala dengan diterbitkannya OSS (online single submission). Kini masyarakat bisa lebih dipermudah melalui system online, sehinga dapat langsung diinput ke dinas, tetapi apabila masyarakat ingin mengurus langsung secara manual dapat langsung melakukannya di masing-masing kecamatan. Sistem online ini yang kini menjadi solusi atas faktor-faktor yang mempengaruhi PUMK (Pelaku Usaha

19Wawancara pada hari Jumat, 01 November 2019, Pukul 08.35 wita di Pusat Pemerintahan Kabupaten Badung 
Mikro Kecil) tidak mengurus izinnya, dengan sistem online, masyarakat atau PUMK yang hendak mengurus izinnya akan sangat dipermudah, sehingga tidak ada alasan lagi para PUMK enggan mengurus izin usahanya.

Adapun tahapan koordinasi antar masing-masing pihak hingga akhirnya informasi mengenai pentingnya izin usaha ini dapat diketahui oleh masyarakat, khususnya pelaku usaha mikro dan kecil sebagai sasaran utamanya, yaitu dimulai dengan Dinas yang mengkoordinasi. Selanjutnya informasi menyebar dari masyarakat ke masyarakat, kemudian apabila ada masyarakat yang ingin mengurus izin usahanya di Kecamatan, akan diarahkan menggunakan system online yang langsung terhubung ke pusat (Puspem). Dengan sistem ini pun sebenarnya tidak diperlukannya pendamping lagi, dikarenakan masyarakat sudah bisa secara mandiri menginput data secara online melalui OSS tadi. Pendampingan hanya ada di Pusat, tetapi jika masing-masing kecamatan membentuk bidang yang harus terjun ke lapangan dan mendampingi masyarakat, maka akan lebih maksimal.

IUMK (Izin Usaha Mikro Kecil) ini ditujukan untuk semua golongan usaha. Dengan sistem OSS (Online Single Submission), maka masa berlaku surat izin usaha itupun menjadi seumur hidup. Selain kemudahan pengurusan yang didapatkan oleh para pelaku usaha, para pelaku usaha juga mendapatkan kelebihan-kelebihan lainnya. Sehingga, tidak ada alasan lagi para pelaku usaha terkhusus usaha mikro dan kecil malas bahkan tidak mau melakukan pengurusan izin usaha.

\section{Kesimpulan}

Legalitas formal suatu badan usaha merupakan suatu keharusan yang dimiliki oleh tiap-tiap pemilik usaha. Legalitas tersebut menandakan suatu badan usaha telah mendapat pengakuan yang sah secara hukum dan resmi untuk dioperasikan. Bertolak dari hasil wawancara, diperoleh informasi kini perkembangannya lumayan membaik dan menunjukkan adanya partisipasi masyarakat terhadap program atau aturan yang telah ditetapkan oleh Pemerintah. Meskipun demikian, tidak dapat dipungkiri dalam penerapannya terdapat beberapa kendala atau faktor-faktor yang mempengaruhi usaha mikro kecil belum mengurus izin usahanya, seperti; SOP yang harus dipenuhi, keterlibatan oknum dalam pengurusan izin secara manual, dan kurangnya sosialisasi serta kesadaran masyarakat. Upaya penyelesaiannya bagi pelaku usaha yang enggan mengurus izinnya secara manual, Pemerintah telah membuatkan program OSS (Online System Submission) sehingga akan lebih mempermudah PUMK mengurus izin usahanya.

\section{Daftar Pustaka}

Buku

Nazir, Mohammad. Metode Penelitian (Jakarta: Penerbit Ghalia Indonesia, 2015).

Sumawinata, Sarbini. Politik Ekonomi Kerakyatan (Jakarta: Gramedia Pustaka Utama, 2004).

Tambunan, Tulus T.H. UMKM di Indonesia (Jakarta: Ghalia Indonesia, 2010).

\section{Jurnal}

Adawiyah, Wiwiek Rabiatul. "Faktor Penghambat Pertumbuhan Usaha Mikro Kecil Menengah (UMKM): Studi di Kabupaten Banyumas". Jurnal Ekonomi Universitas Jenderal Soedirman. 2013. 
Dewi, Gusti Ayu Krisna, Putu Nomy Yasintha dan Putu Eka Purnamaningsih. "Implementasi Kebijakan Izin Usaha Mikro dan Kecil (IUMK) di Kecamatan Denpasar Barat". Jurnal Ilmu Sosial dan Ilmu Politik Universitas Udayana.

International Labour Organization. 2014. "Policies for The Formalization of Micro and Small Enterprises". Latin America And the Caribbean: Author.

Julita, Ami. "Pelaksanaan Izin Usaha Mikro dan Kecil (IUMK) Gratis di Kecamatan Sukajadi Kota Pekanbaru." Jurnal JOM FISIP 4, No. 1 (2017).

Kusmanto, Heri dan Warjito. "Pentingnya Legalitas Usaha Bagi Usaha Mikro Kecil dan Menengah". JUPIIS: Jurnal Pendidikan Ilmu-Ilmu Sosial, 11 (2) (2019).

Lestari N., Ayu. "Penerapan Izin Usaha Mikro dan Kecil di Kecamatan Tampan Pekanbaru". Jurnal Administrasi Negara FISIP Universitas Riau, 4 (2017).

Putra, Gede Surya Prtama dan Mustika, Made Dwi Setyadhi. “Efektivitas Program Jamkrida Dan Dampak Terhadap Pendapatan Dan Penyerapan Tenaga Kerja UMKM". E-Jurnal Ekonomi Pembangunan Universitas Udayana 3, No. 12 (2014).

Suwandi. "Perizinan Usaha UMKM, Buletin Peraturan di Bidang Koperasi dan UMKM, Kementerian Koperasi dan UKM". Volume 3 Juni 2012.

Tampan, Abner., Rumapea, Patar \& Pombengi, Jericho. “Implementasi Kebijakan Pemberian Izin USAha Mikro dan Kecil di Kantor Kecamatan Malalayang Kota Manado". Jurnal Universitas Sam Ratulangi. 2016.

\section{$\underline{\text { Tesis }}$}

Harahap, J. K. (2018). Analisis Kontribusi Usaha Mikro Kecil Menengah (UMKM) Terhadap Pengembangan Wilayah di Kecamatan Medan Johor Kota Medan.

PRATIVI, F. M. (2019). Faktor-Faktor yang Mempengaruhi Produksi Usaha Mikro Kecil dan Menengah (UMKM) Berbasis Ekonomi Kreatif di Kabupaten Ciamis (Doctoral dissertation, Universitas Jenderal Soedirman).

SORMIN, H. S. (2016). PERAN IZIN USAHA DALAM PEMBERDAYAAN USAHA MIKRO, KECIL, DAN MENENGAH (Doctoral dissertation, Universitas Airlangga).

\section{Peraturan Perundang-Undangan}

Republik Indonesia. 2008. Undang-Undang Republik Indoensia Nomor 20 tahun 2008 tentang UMKM.

Republik Indonesia. 2014. Peraturan Menteri Dalam Negeri Nomor 83 Tahun 2014 Tentang Pedoman Pemberian Izin Usaha Mikro dan Kecil, Pasal 9 ayat 5.

Republik Indonesia. 2014. Peraturan Presiden Nomor 98 Tahun 2014 Tentang Perizinan Untuk Usaha Mikro dan Kecil, Pasal 2. 